\title{
Development Of Batik Mangrove As A Community Empowerment Effort In The Banyuurip Village Ujung Pangkah Gresik
}

\author{
Authors \\ Ummu Aliyah ${ }^{1}$, Mohamad Hariyadi ${ }^{2}$, Prihadi $^{3}$ \\ Correspondence \\ ${ }^{1}$ Teknik Industri -STTQ, ${ }^{2}$ Teknik Elektro -STTQ, ${ }^{3}$ Teknik Industri -STTQ \\ Email: umualiy@yahoo.co.id
}

\begin{abstract}
Fishing group Tirta Buana, around the beach of Banyuurip village, Ujung-Gresik. Cooperate with FERTILIZER and PT. PGN SAKA is Limited to hold the center of seedlings and mangrove sales. Until then from this mangrove business make a new tourist destination called Banyuurip Mangrove Center (BMC). Mangrove Banyuurip Ujungsemini lately visited by many domestic tourists. It is located about 35 kilometers from the city of Surabaya or about 23 kilometers from the city of Gresik to the north. The average day of visitors who come 600 people, but at the time of the feast can reach 1,600 visitors. The large number of tourists who come to enjoy the beautiful panorama of Mangrove if handled precisely will bring their source of income for the community Banyu Urip, the tip of the step has not been optimally absorbed. Several business opportunities will be directed in this Community Partnership program which includes: the empowerment of mangrove crops such as batik handicrafts made from mangrove, dodol mangrove and syrup made from mangrove. Seafood products are also the potential for the development of the production of the main shells. Besides the improvement of the facilities and Preasarana mangrove forest itself needs to be beautified so that visitors energy comfortable and feel at home in enjoying tourism of the BMC Mangrove such as The Making of jogging track to the shore of white sand, Gazebo level that So that tourists can see mangrove forests from above as well as repair and illumination of the road to access tourist attractions.
\end{abstract}

Keywords: Development of Batik Mangrove, Community empowerment, Banyuurip Village Ujungpangkah.

Received: 15 Januari 2020. Accepted: 20 Januari 2020

\section{Introduction}

Banyuurip is a village in the district of Ujung Pangkah, Gresik Regency, East Java province. With a location of about 35 kilometers from the city of Surabaya or about 23 kilometers from the city of Gresik to the north, the area began to start as a new ecotourism destination with the claimed visitors continue to increase. "If the holidays, there are usually about six hundred visitors. Even on Eid al-Fitr yesterday, there are as many as 1600 visitors who come to visit here, "(Kompas. com," Taman Wisata Mangrove, a new tourist destination in Gresik "). Many of his visitors who enjoy this ecotourism is a challenge and opportunity. The challenge to continue to increase the number of visitors entering by creating ecotourism branding Banyuurip Mangrove Center (BMC) and business opportunities by opening the creative economic business by utilizing the seafood and waste of unused.

Eko with Banyu urip Mangrove Center (BMC) is not a one-on-one mangrove tourism area in the district end step there is another similar area in the village of Wetan called Muara Bengawan Solo (SBM). Nevertheless, these two regions have a difference in reaching a tourist site which is for the SBM visitors must follow the estuary of the river Bengawan solo first until the Kewisata mangrove while BMC directly through the road that is the means to the location Tour bypassing the fishing village. Many facilities and infrastructures that must be improved to improve the branding of $\mathrm{BMC}$ to better attract tourists who want to visit mangrove tourism destinations among them are like: Jogging track to the edge of white sand beach, Gazebo high level so that tourists can see the mangrove forest from above as well as repair and lighting the road to 
access tourist attractions. During this time the access road to mangrove tourism is still the makings of macadam so that when the rainy season arrives the street becomes a Becek, with a light street lighting that is still nil. The Gazebo is built 3 pieces with a new 250-meter jogging track built, with the addition of about 350 meters again will be translucent by the beach. Besides that it is not less important in increasing this eco-tourism is the branding BMC. For that, there will be training that is insightful and mangrove made, such as batik craft training. Batik flavored Mangrove, Besides can be souvenirs for the environmentally sound tourism area, can also be sold larger market.

\section{Method}

\section{Development of Ecotourism village facilities and infrastructure}

Training on batik from mangrove material facilities and infrastructure is developed along with the needs of the market and the availability of funds from the village or other sources such as CSR or funds from the local government of Gresik Regency. With the deliberations between the parties concerned both the village government, the group of fishermen Tirta Buana and KOPDARWIS (Tourism conscious Group) than in the Community Empowerment program, both related to the infrastructure and economic sectors through training Batik that will display a typical batiurip made from mangrove.

\section{Community Economic Development.}

The development of the Community economy is done that is affected as a tourism village because of the existence of the ecotourism. People can certainly be built to create a business-a creative business that supports the comfort of tourists enjoys the mangrove tour. Batik training is a good choice to showcase the unique eye of the village of Banyuurip.

\section{Results And Discussion}

Batik training is an opportunity to improve the economic activity of the village community in Banyuurip. After this initial training activity as a basis, it needs to be upgraded further, i.e. the activity of participants that more leads to the making of patterns and looking for market share. If this activity is successful then it is expected to arise artistic creativity from participants who create a pattern of tasteful batik in the typical mangrove Banyuurip. The strategy that can be applied to the continuation of batikmangrove skills that still belong to the category of strategy weaknessesthreats (W-T) is to increase cooperation with related institutions.

Cooperation in a business is very important to do, both from fellow entrepreneurs, governments, and banks. Cooperation with the Government, the pemdes can simultaneously conduct promotion to other areas through exhibitions that are usually followed and carried out by governments especially local governments Banking support is indispensable by pemdes to strengthen funding for the sustainability of an effort. Therefore, the pemdes with the bank must cooperate. Such cooperation is certainly in a mutually beneficial form of symbiotic mutualism. It means that the bank as a lender benefits from the borrower in the form of interest. But the interest does not burden entrepreneurs in the process of payment.

With the loan, pemdes can improve facilities and infrastructure related to the business that is carried out especially in the procurement of equipment. This strategy is expected to minimize weaknesses owned such as skills and knowledge that still lacking, low information and technology mastery, limited capital and business work management.

\section{Conclusion}

- Community Empowerment through Batik Craft Training provides its appeal to BMC mangrove ecotourism

- This empowerment is also an added value for the skills of the Economic Value Society

- Batik Mangrove Banyuurip will be a trademark that can be marketed to visitors ecotourism or community Gresik through regional exhibitions.

- The continuation of batik training is very desirable to create this Banyuurip village as one of the centers in the Gresik Regency.

\section{References}

Faturochman, et.al. (2007). Membangun Gerakan Penanggulangan Kemiskinan Melalui Pemberdayaan Masyarakat. Pusat Studi Kependudukan dan Kebijakan. Yogjakarta : Universitas Gadjah Mada. 
Hasibuan, Melayu S.P. (2002). Manajemen Sumber Daya Manusia. Edisi Revisi. Jakarta : Bumi Aksara.

Dinas Kelautan, Perikanan Dan Peternakan.(2000). Luas Lahan Mangrove Di Kabupaten Gresik Tahun 2000. Gresik.

Ariestonandri, Prima (2006), "Marketing Research For Beginner", Penerbit CV. Andi Offset, Yogyakarta.

Kotler, Philip., Keller, Kevin Lane (2007). "Manajemen Pemasaran". Penerbit PT. Indeks, Jakarta.

.Machfoedz, Mahmud (2010). "Komunikasi Pemasaran Moderen". Penerbit Cakra Ilmu,Yogyakarta. 